in vivo $34: 1047-1052(2020)$

doi:10.21873/invivo.11874

\title{
Association of Murine Double Minute 2 Genotypes and Lung Cancer Risk
}

\author{
YU-CHAO LIN ${ }^{1}$, WEN-SHIN CHANG ${ }^{2}$, TE-CHUN SHEN ${ }^{2}$, HSIN-TING LI ${ }^{2,3}$, CHIA-HSIANG LI ${ }^{2}$, \\ YU-CHEN HSIAU ${ }^{2}$, YUN-CHI WANG ${ }^{2}$, CHENG-NAN WU ${ }^{4}$, CHI-LI GONG $^{2}$, ZHI-HONG WANG ${ }^{5}$, \\ CHIA-WEN TSAI ${ }^{2,4}$, TE-CHUN HSIA ${ }^{2}$ and DA-TIAN BAU ${ }^{1,2,6}$ \\ ${ }^{1}$ Graduate Institute of Clinical Medical Science, China Medical University, Taichung, Taiwan, R.O.C.; \\ ${ }^{2}$ Terry Fox Cancer Research Laboratory, Department of Medical Research, \\ China Medical University Hospital, Taichung, Taiwan, R.O.C.; \\ ${ }^{3}$ Department of Biomedical Imaging and Radiological Science, \\ China Medical University, Taichung, Taiwan, R.O.C.; \\ ${ }^{4}$ Department of Medical Laboratory Science and Biotechnology, \\ Central Taiwan University of Science and Technology, Taichung, Taiwan, R.O.C.; \\ ${ }^{5}$ Department of Food Nutrition and Health Biotechnology, Asia University, Taichung, Taiwan, R.O.C.; \\ ${ }^{6}$ Department of Bioinformatics and Medical Engineering, Asia University, Taichung, Taiwan, R.O.C.
}

\begin{abstract}
Aim: The aim of this study was to evaluate the contribution of human mouse double minute 2 (MDM2) gene polymorphisms to the risk of Taiwan lung cancer. Materials and Methods: In this case-control study, the association of MDM2 rs2279744 genotypes with lung cancer risk was investigated among 358 lung cancer patients and 716 agegender-and smoking status- matched controls in Taiwan. Results: The percentages of MDM2 rs2279744 GT and GG genotypes were $50.0 \%$ and $27.4 \%$ in lung cancer group and $50.0 \%$ and $26.5 \%$ in control group, respectively [odds ratio $(O R)=1.03$ and $1.07,95 \%$ confidence interval $(C I)=0.75$ 1.43 and $0.75-1.53$, respectively]. The analysis about allelic frequency showed that $G$ allele at MDM2 rs2279744 conferred a non-significant increased cancer risk $(O R=1.03$, 95\%CI=0.86-1.24). Conclusion: Polymorphisms of MDM2 rs2279744 may play a role in lung carcinogenesis. However, the studied genotypes were not shown as predictors of lung cancer susceptibility.
\end{abstract}

This article is freely accessible online.

Correspondence to: Da-Tian Bau, Te-Chun Hsia and Chia-Wen Tsai Terry Fox Cancer Research Laboratory, China Medical University Hospital, 2 Yuh-Der Road, Taichung, 404 Taiwan, R.O.C. Tel: +886 422053366 (Ext. 5805), e-mail: datian@mail.cmuh.org.tw; artbau2@gmail.com (D.-T. Bau)

Key Words: Mouse double minute 2, MDM2, polymorphisms, genotypes, lung cancer, Taiwan.
According to GLOBOCAN 2018 statistics about cancer occurrence and mortality reported by the International Agency for Research on Cancer, lung cancer is the first cause of cancer death, accounting for about 2.1 million newly-diagnosed cases and 1.8 million deaths worldwide (1). Thus, it is urgently important for translational scientists to figure out effective methodologies predicting and preventing the risk of lung cancer, improving prognosis and extending the survival periods for the lung cancer patients.

The initiation and development of lung cancer is related to complicated factors including environmental, lifestyle, and genomic discrepancies, among which cigarette smoking behavior is the most risk one (2). Nevertheless, $10 \%$ to $25 \%$ of the lung cancer patients are non-smokers worldwide, and this fact indicates that the personal genomic factors also play as determiners of carcinogenesis for personal lung cancer etiology (3). In Taiwan, the incidence and mortality of lung cancer has occupied the third and first places among the common cancers for decades (4). In Taiwan, although several clinically useful genomic biomarkers for the prediction, diagnosis, and prognosis of lung cancer risk have been proposed during the recent years (5-10), the investigations about clinically practical genomic markers and the intracellular mechanisms are still in urgent need.

Mouse double minute 2 homolog (MDM2; also known as E3 ubiquitin-protein ligase), encoded by the $M D M 2$ gene in human genome, acts as an E3 ubiquitin ligase, recognizing the N-terminal trans-activation domain at p53, and also suppresses the activation of p53 transcription. The most common single nucleotide polymorphism (SNP) of MDM2 gene is known as "rs2279744, "SNP309", and 
in vivo $34: 1047-1052(2020)$

Table I. Summary of selected demographics of the 358 patients with lung cancer and the 716 matched controls.

\begin{tabular}{|c|c|c|c|c|c|c|c|}
\hline \multirow[t]{2}{*}{ Characteristics } & \multicolumn{3}{|c|}{ Controls $(\mathrm{n}=716)$} & \multicolumn{3}{|c|}{ Patients $(n=358)$} & \multirow[t]{2}{*}{$p$-Value } \\
\hline & $\mathrm{n}$ & $\%$ & Mean (SD) & $\mathrm{n}$ & $\%$ & Mean (SD) & \\
\hline Age (years) & & & $64.8(6.8)$ & & & $64.0(6.9)$ & 0.5871 \\
\hline \multicolumn{8}{|l|}{ Gender } \\
\hline Male & 488 & $68.1 \%$ & & 254 & $70.9 \%$ & & \\
\hline Female & 228 & $31.9 \%$ & & 104 & $29.1 \%$ & & 0.3642 \\
\hline \multicolumn{8}{|l|}{ Smoking status } \\
\hline Ever smokers & 563 & $78.6 \%$ & & 293 & $81.8 \%$ & & \\
\hline Non-smokers & 153 & $21.4 \%$ & & 65 & $18.2 \%$ & & 0.2282 \\
\hline \multicolumn{8}{|l|}{ Histology } \\
\hline Adenocarcinoma & & & & 218 & $60.9 \%$ & & \\
\hline SCC & & & & 106 & $29.6 \%$ & & \\
\hline Other & & & & 34 & $9.5 \%$ & & \\
\hline
\end{tabular}

aBased on Chi-square test without Yates' correction; SCC, Squamous cell carcinoma; SD, standard deviation.

"SNP309T>G"; it has been examined for its role in cancer etiology and treatment responses. MDM2 rs2279744 has been identified as a $\mathrm{T}$ to $\mathrm{G}$ substitution at the nucleotide 309 in the first intron, regulating the binding affinity between MDM2 and transcription factor Sp1 (11). In literature, MDM2 rs2279744 has been reported to be closely related to accelerated tumor formation in both hereditary and sporadic cancers and to serve as a rat-limiting factor during tumorigenesis (11). Thus, it is hypothesized that the genomic variant may critically determine the expression level of MDM2 and influence individual's susceptibility to several types of cancer. In literature, several studies have examined the contribution of MDM2 rs2279744 genotypes to various tumors, while the results are not so conclusive among the different ethnicities investigated and various types of cancer (12-14). Some studies have proposed a direct association between MDM2 rs2279744 and cancer risk (15-20); however, other reports have not confirmed this finding (21-24).

In 2008, Liu and his colleagues have reported that there is no significant association between MDM2 rs2279744 genotypes and lung cancer risk among Caucasians (25). The group of Hancox reported that the $\mathrm{G}$ allele at MDM2 rs2279744 was associated with not only higher MDM2 expression levels, but also with a reduced p53 response, and hence more DNA damage and the corresponding tissue destruction. Interestingly, the $\mathrm{G}$ allele was associated with accelerated smoking-related decline in lung function (26). According to the literature mentioned above, MDM2 genotype and its expression may contribute to the etiology of lung cancer risk. Therefore, the aim of the current study was to reveal the genotypes of MDM2 rs2279744 among Taiwanese and evaluate their association with lung cancer risk, in Taiwan.

\section{Materials and Methods}

Selection of lung cancer patients and controls. Three hundred and fifty-eight patients with lung cancer were histologically confirmed and recruited at the medical center in central Taiwan with the approval of the Institutional Review Board of China Medical University Hospital (DMR100-IRB-284), as previously described $(5,6,10)$. Briefly, the exclusion criteria of the cases were: history of any other malignancy and pulmonary diseases, such as chronic obstructive pulmonary disease (COPD), pneumothorax, and asthma. During the same period, 760 healthy volunteers were selected from the databank of Health Examination Cohort of China Medical University Hospital with more than 15,000 individuals as controls, matched for their age (differences less than 5 years), gender, and smoking behavior. The exclusion criteria of the control group included previous malignancy, metastasized cancer from other known or unknown origin, and any genetic or familial diseases. The controls and cases were all Taiwanese; their selected recorded characteristics are summarized in Table I.

Genotyping conditions for MDM2 rs2279744. Extraction of genomic DNA from peripheral blood leukocytes was conducted within $24 \mathrm{~h}$ with the QIAamp Blood Mini kit (Blossom, Taipei, Taiwan) as usual $(27,28)$. Then the DNA was quantified, stored long-term at $-80^{\circ} \mathrm{C}$, diluted and aliquoted for genotyping as a working stock at $-20^{\circ} \mathrm{C}$ as is routinely conducted $(29,30)$. The MDM2 genotyping working flow including the designing of the forward and reverse primer sequences, the selection of corresponding restriction endonucleases, and the polymerase chain reaction (PCR) cycling condition set-up were previously described (31). Briefly, the cycling conditions of PCR procedure were set as: one cycle at $94^{\circ} \mathrm{C}$ for $5 \mathrm{~min}$; followed by 35 cycles of $94^{\circ} \mathrm{C}$ for $30 \mathrm{~s}, 59^{\circ} \mathrm{C}$ for $30 \mathrm{~s}$ and $72^{\circ} \mathrm{C}$ for $30 \mathrm{~s}$; last, an extension at $72^{\circ} \mathrm{C}$ for $10 \mathrm{~min}$. The PCR products were harvested immediately after the final extension, and subjected to DNA electrophoresis. The sequences for the forward and reverse primers were 5'-GTTTTGTTGGACTGGGGCTA-3' and 5'CTGCGATCATCCGGACCT-3', respectively. After the first check of successful PCR amplification procedures, all the PCR products 
Table II. Distributions of MDM2 rs2279744 genotypic frequencies among lung cancer patients and healthy controls.

\begin{tabular}{lccccc}
\hline & Patients, $\mathrm{n}(\%)$ & Controls, $\mathrm{n}(\%)$ & OR $(95 \% \mathrm{CI})^{\mathrm{a}}$ & ${\text { Adjusted OR }(95 \% \mathrm{CI})^{\mathrm{a}}}$-Value $^{\mathrm{b}}$ \\
\hline TT & $81(22.6)$ & $168(23.5)$ & 1.00 (Reference) & 1.00 (Reference) \\
GT & $179(50.0)$ & $358(50.0)$ & $1.03(0.75-1.43)$ & $1.06(0.78-1.39)$ & 0.8238 \\
GG & $98(27.4)$ & $190(26.5)$ & $1.07(0.75-1.53)$ & $1.14(0.81-1.66)$ & 0.7135 \\
GT+GG & $277(77.4)$ & $548(76.5)$ & $1.04(0.78-1.42)$ & $1.08(0.82-1.47)$ & 0.7590 \\
$p_{\text {trend }}$ & & & & & 0.9348 \\
\hline
\end{tabular}

OR, Odds ratio; CI, confidence interval; aData have been adjusted for confounding factors age, gender and smoking status; ${ }^{b} \mathrm{Based}$ on Chi-square test without Yates' correction.

were enzymatically digested by MspA II restriction endonuclease (New England Biolabs, Beverly, MA, USA) and then separated and identified of their MDM2 genotypes using 3\% agarose gel electrophoresis. All the genotypic processing was repeated by at least two expert scientists in our team independently and blindly, as expected, the results were $100 \%$ concordant to each other.

Statistical analysis methods. The typical unpaired Student's $t$-test was applied to compare the distributions of continuous variables such as ages between the lung cancer patients and the control groups. The Pearson's Chi-square was applied in comparison of the distributions of the $M D M 2$ genotypes among the investigated subgroups in comparison. The associations between MDM2 polymorphic genotypes and lung cancer risk were estimated by calculating the odds ratios (ORs) and the responding 95\% confidence intervals (CIs) within logistic regression analysis. Statistically, any comparison with $p$-value less than 0.05 was identified as significantly different to each other.

\section{Results}

The distributions of age, sex and smoking status for the 358 lung cancer patients and 716 non-cancer healthy controls, are summarized and compared in Table I. In addition, the histology of the lung cancer patients are also collected at the bottom of Table I. Since we have applied the matching strategies focusing on age, gender and smoking status to recruit those 716 noncancer healthy subjects as controls, the comparison results showed that there was no difference in respect to the distributions of age, gender and smoking behavior between the case and control groups ( $p$-values all $>0.05$ ) (Table I). Among the lung cancer patients, $60.9 \%$ (218/358) were adenocarcinoma type, $29.6 \%$ (106/358) were squamous cell carcinoma type, and $9.5 \%$ (34/358) were other types.

The distributions of the MDM2 rs2279744 genotypes among the 358 lung cancer patients and 716 non-cancer healthy controls are presented in Table II. Overall, the genotypes of MDM2 rs2279744 were non-differentially distributed between the case and control groups ( $p$ for trend=0.9348) (Table II). In detail, neither the MDM2 rs2279744 GG nor the GT was associated with altered lung cancer risk, compared to the wild-type TT genotype (crude $\mathrm{OR}=1.03$ and $1.07,95 \% \mathrm{CI}=0.75-1.43$ and $0.75-1.53, p=0.8238$ and 0.7135 , respectively). After adjusting the confounding factors, the trends were still the same (adjusted $\mathrm{OR}=1.06$ and $1.14,95 \% \mathrm{CI}=0.78-1.39$ and $0.81-1.66$, respectively). In the dominant model, there was still a non-significant association between the GT+GG genotype of MDM2 rs2279744 and lung cancer risk, compared to the TT wild-type genotype before and after adjusting those confounding factors.

So as to confirm the findings deduced from Table II, we have further conducted the analysis of allelic frequency distributions for the MDM2 rs2279744 and the results are shown in Table III. In consistence with the idea that MDM2 rs2279744 genotype was not associated with lung cancer risk, the percentage of allele $\mathrm{G}$ was $52.4 \%$ among the lung cancer patients, non-significantly higher than that of $51.5 \%$ among the non-cancer controls (crude and adjusted ORs $=1.03$ and 1.06, respectively) (Table III).

\section{Discussion}

The role of MDM2 in carcinogenesis can be both p53dependent and p53-indepnedent. First, MDM2 is originally recognized as an oncoprotein which can directly bind to tumor suppressor p53 and down-regulate its tumor suppressive capacity. After binding with p53, MDM2 enhances the expression of p53 and the p53-mediated transactivation of MDM2, which in turn team up together to suppress the growth of soft tissue sarcomas, osteosarcomas and esophageal sarcomas $(32,33)$. Therefore, in the very beginning, the oncogenic properties of MDM2 were identified as p53-dependent. However, there are also some investigations showing that MDM2 is able to directly interact with other tumor suppressor proteins in p53-deficient cells $(34,35)$. In the same context, elevated expression of MDM2 by Ras/Raf/MEK/MAP kinase cascade has been observed in p53-deficient cells (36). All these findings indicate that the oncogenic function of MDM2 may be p53-independent.

Regarding the regulation of the MDM2 protein level, the case is more complicated. It has been found that MDM2 expression levels might be regulated at the post-transcriptional level $(37,38)$. The aforementioned literature all supported the idea that the complex molecular mechanisms underlying the 
in vivo $34: 1047-1052(2020)$

Table III. Allelic frequencies for MDM2 rs2279744 polymorphisms among lung cancer patients and healthy controls.

\begin{tabular}{|c|c|c|c|c|c|}
\hline Allelic type & $\begin{array}{c}\text { Patients, } \mathrm{n}(\%) \\
\mathrm{n}=358 * 2=716\end{array}$ & $\begin{array}{l}\text { Controls, n (\%) } \\
\mathrm{n}=716 * 2=1432\end{array}$ & $\begin{array}{l}\text { Crude OR } \\
(95 \% \mathrm{CI})^{\mathrm{a}}\end{array}$ & $\begin{array}{c}\text { Adjusted OR } \\
(95 \% \mathrm{CI})^{\mathrm{a}}\end{array}$ & $p$-Value \\
\hline Allele $\mathrm{T}$ & 341 (47.6) & $694(48.5)$ & 1.00 (Reference) & 1.00 (Reference) & \\
\hline Allele G & $375(52.4)$ & $738(51.5)$ & $1.03(0.86-1.24)$ & $1.06(0.84-1.32)$ & 0.7141 \\
\hline
\end{tabular}

OR, Odds ratio; CI, confidence interval; aData have been adjusted for confounding factors age, gender and smoking status; bBased on Chi-square test without Yates' correction.

regulation network of $M D M 2$ gene at DNA, RNA and protein levels during tumorigenesis are largely unrevealed. Considering that MDM2 rs2279744 may closely be responsible for the regulation of MDM2 protein expression in addition to its interaction with $\mathrm{p} 53$, it is of great value to figure out its contribution to cancer susceptibility determination.

In the study, we have firstly provided solid evidence for that variant GT or TT genotype at MDM2 rs2279744 was not associated with Taiwan lung cancer risk (Table II). Also, allele $\mathrm{T}$ or $\mathrm{G}$ may not serve as a predictor for lung cancer occurrence (Table III). According to previous lung cancer genomic studies, whether MDM2 rs2279744 has a contribution to lung carcinogenesis is still controversial. In detail, some positive findings have supported that the GT and GG genotypes at MDM2 rs2279744 are associated with higher cancer risk than the wild-type TT genotype (15-20), whereas, other reports have shown no significant association with altered cancer risk (21-24). In Taiwanese population included in the present study, the MDM2 rs2279744 homo-variant GG carriers, but not GT, were found to have an increased CRC risk compared with those carrying TT genotype (31). However, MDM2 rs2279744 genotypes were not associated with lung cancer risk (Tables II and III).

Cigarette smoking is the major environmental risk factor for lung cancer, especially for non-small cell lung cancer (NSCLC) (39). Several compounds in cigarettes may induce DNA damage, thus contributing to carcinogenesis $(40,41)$. The tumor suppressor protein p53 plays a crucial role in the prevention of cancer initiation through cell cycle arrest, DNA repair, and apoptosis in case of DNA repair failure (42-44). MDM2 gene acts as a negative regulator of $\mathrm{p} 53$, and overexpression of MDM2 has been reported in many types of cancer tissues (45). In this study, we investigated the associations between the functional single nucleotide polymorphism of MDM2 rs2279744 and the risk of lung cancer in a large Taiwanese population. An overall association was not found (Tables II and III), and genesmoking interaction analyses indicated that the variant genotypes were associated with higher risk of lung cancer neither in never smokers nor in ever smokers (data not shown). It has been reported by Liu and his colleagues that although the overall MDM2 rs2279744 genotypes are not associated with lung cancer risk among Caucasians, there is a statistically significant interaction between smoking and MDM2 genotypes. Their stratified analysis according to individual pack-years of smoking status demonstrated that the GG genotype, compared to wild-type T/T genotype, contribute to higher risk for never and mild ( $<30$ packyears) smokers, while to lower risk for moderate (30-57 pack-years) and heavy smokers ( $\geq 58$ pack-years) (25). Further investigations are warranted to elucidate the interaction among $M D M 2$ genotype, phenotype and smoking status.

There are several limitations of the current study. Despite the power and the representativeness of the current study, with 358 lung cancer patients and 358 controls are examined as well, a larger number of the overall population would be necessary to further examine the contributions of specific genotypes to lung cancer risk and prognosis. In addition, lung cancer patients can be further classified according to characteristics, such as gender and smoking status, or according to their cancer type, to improve the clinical applicability of the study results.

In conclusion, MDM2 rs2279744 was not associated with lung cancer risk in a representative Taiwanese population. In the near future, we are going to validate the combined effects of p53 and MDM2 on Taiwan lung cancer risk. Validation of our findings in larger population-based studies and in different ethnicities are needed.

\section{Conflicts of Interest}

All the Authors have declared no conflicts of interest regarding this study.

\section{Authors' Contributions}

Research design: Lin YC and Chang WS; patient and questionnaire summaries: Lin YC, Shen TC, $\mathrm{Li} \mathrm{CH}$ and Hsia TC; experimental work: Wang YC, Li HT and Hsiau YC; statistical analysis: Wang $\mathrm{ZH}, \mathrm{Wu} \mathrm{CN}$ and Gong CL; article writing: Tsai CW and Bau DT; review and revision: Chang WS, Tsai $\mathrm{CW}$ and Bau DT. 


\section{Acknowledgements}

The Authors appreciate the team of Hsia, Y.-C. Lin, T.-C. Shen and others in collection of all the participants. The perfect technology and efforts from Yu-Ting Chin, Tai-Lin Huang, Yu-Hsin Lin and Yi-Ru Huang are appreciated. This study is supported by the grant from China Medical University Hospital and Asia University (CMU108-ASIA-02).

\section{References}

1 Bray F, Ferlay J, Soerjomataram I, Siegel RL, Torre LA and Jemal A: Global cancer statistics 2018: GLOBOCAN estimates of incidence and mortality worldwide for 36 cancers in 185 countries. CA Cancer J Clin 68: 394-424, 2018. PMID: 30207593. DOI: $10.3322 /$ caac.21492

2 Malhotra J, Malvezzi M, Negri E, La Vecchia C and Boffetta P: Risk factors for lung cancer worldwide. Eur Respir J 48: 889902, 2016. PMID: 27174888. DOI: 10.1183/13993003.003592016

3 Rivera GA and Wakelee H: Lung cancer in never smokers. Adv Exp Med Biol 893: 43-57, 2016. PMID: 26667338. DOI: 10.1007/978-3-319-24223-1_3

4 Taiwan Ministry of Health and Welfare Clinical Trial and Research Center of Excellence: Cancer Registration Annual Report. Available at: https://www.hpa.gov.tw/Pages/List.aspx? nodeid=269 (Accessed on January 12th, 2020)

5 Chen GL, Wang SC, Shen TC, Tsai CW, Chang WS, Li HT, Wu $\mathrm{CN}$, Chao CY, Hsia TC and Bau DT: The association of matrix metalloproteinas-2 promoter polymorphisms with lung cancer susceptibility in Taiwan. Chin J Physiol 62: 210-216, 2019. PMID: 31670285. DOI: 10.4103/CJP.CJP_43_19

6 Chen GL, Wang SC, Huang WC, Chang WS, Tsai CW, Li HT, Shen TC, Hsia TC and Bau DT: The association of MMP-11 promoter polymorphisms with susceptibility to lung cancer in Taiwan. Anticancer Res 39: 5375-5380, 2019. PMID: 31570432. DOI: 10.21873/anticanres.13731

7 Shen TC, Chang WS, Hsia TC, Li HT, Chen WC, Tsai CW and Bau DT: Contribution of programmed cell death 6 genetic variations, gender, and smoking status to lung cancer. Onco Targets Ther 12: 6237-6244, 2019. PMID: 31496727. DOI: 10.2147/OTT.S205544

8 Wu MF, Wang YC, Li HT, Chen WC, Liao CH, Shih TC, Chang WS, Tsai CW, Hsia TC and Bau DT: The contribution of interleukin-12 genetic variations to Taiwanese lung cancer. Anticancer Res 38: 6321-6327, 2018. PMID: 30396953. DOI: 10.21873/anticanres.12989

9 Chen GL, Shen TC, Chang WS, Tsai CW, Li HT, Chuang CL, Lai YL, Yueh TC, Hsia TC, Wang SC and Bau DT: The contribution of MMP-7 promoter polymorphisms to Taiwan lung cancer susceptibility. Anticancer Res 38: 5671-5677, 2018. PMID: 30275186. DOI: 10.21873/anticanres.12903

10 Shen TC, Chang WS, Tsai CW, Chao CY, Lin YT, Hsiao CL, Hsu CL, Chen WC, Hsia TC and Bau DT: The contribution of matrix metalloproteinase-1 promoter genotypes in Taiwan lung cancer risk. Anticancer Res 38: 253-257, 2018. PMID: 29277780. DOI: 10.21873 /anticanres.12215

11 Bond GL, Hu W, Bond EE, Robins H, Lutzker SG, Arva NC, Bargonetti J, Bartel F, Taubert H, Wuerl P, Onel K, Yip L, Hwang SJ, Strong LC, Lozano G and Levine AJ: A single nucleotide polymorphism in the MDM2 promoter attenuates the p53 tumor suppressor pathway and accelerates tumor formation in humans. Cell 119: 591-602, 2004. PMID: 15550242. DOI: 10.1016/j.cell.2004.11.022

12 Lind H, Zienolddiny S, Ekstrom PO, Skaug V and Haugen A: Association of a functional polymorphism in the promoter of the MDM2 gene with risk of nonsmall cell lung cancer. Int J Cancer 119: 718-721, 2006. PMID: 16496380. DOI: 10.1002/ijc.21872

13 Hong Y, Miao X, Zhang X, Ding F, Luo A, Guo Y, Tan W, Liu $\mathrm{Z}$ and Lin D: The role of P53 and MDM2 polymorphisms in the risk of esophageal squamous cell carcinoma. Cancer Res 65: 9582-9587, 2005. PMID: 16230424. DOI: 10.1158/00085472.CAN-05-1460

14 Ma H, Hu Z, Zhai X, Wang S, Wang X, Qin J, Jin G, Liu J, Wang X, Wei Q and Shen H: Polymorphisms in the MDM2 promoter and risk of breast cancer: a case-control analysis in a Chinese population. Cancer Lett 240: 261-267, 2006. PMID: 16288830. DOI: 10.1016/j.canlet.2005.09.019

15 Alazzouzi H, Suriano G, Guerra A, Plaja A, Espin E, Armengol M, Alhopuro P, Velho S, Shinomura Y, Gonzalez-Aguilera JJ, Yamamoto H, Aaltonen LA, Moreno V, Capella G, Peinado MA, Seruca R, Arango D and Schwartz S, Jr.: Tumour selection advantage of non-dominant negative P53 mutations in homozygotic MDM2-SNP309 colorectal cancer cells. J Med Genet 44: 75-80, 2007. PMID: 16825434. DOI: 10.1136/jmg. 2006.042572

16 Joshi AM, Budhathoki S, Ohnaka K, Mibu R, Tanaka M, Kakeji Y, Maehara Y, Okamura T, Ikejiri K, Futami K, Maekawa T and Yasunami Y: TP53 R72P and MDM2 SNP309 polymorphisms and colorectal cancer risk: the Fukuoka Colorectal Cancer Study. Jpn J Clin Oncol 41: 232-238, 2011. PMID: 21051533. DOI: 10.1093/jjco/hyq200

17 Chaar I, Arfaoui TA, El Amine el HO, Mahmoud LB, Khiari M, Sammoud S, Lounis A, Amara S, Gharbi L, Hmida AB, Mzabi $\mathrm{S}$ and Bouraoui S: Impact of MDM2 polymorphism: increased risk of developing colorectal cancer and a poor prognosis in the Tunisian population. Eur J Gastroenterol Hepatol 24: 320-327, 2012. PMID: 22266832. DOI: 10.1097/MEG.0b013e32834bdf84

18 Phang BH, Linn YC, Li H and Sabapathy K: MDM2 SNP309 G allele decreases risk but does not affect onset age or survival of Chinese leukaemia patients. Eur J Cancer 44: 760-766, 2008. PMID: 18313915. DOI: 10.1016/j.ejca.2008.02.007

19 Walsh CS, Miller CW, Karlan BY and Koeffler HP: Association between a functional single nucleotide polymorphism in the MDM2 gene and sporadic endometrial cancer risk. Gynecol Oncol 104: 660-664, 2007. PMID: 17123590. DOI: 10.1016/ j.ygyno.2006.10.008

20 Paulin FE, O'Neill M, McGregor G, Cassidy A, Ashfield A, Ali CW, Munro AJ, Baker L, Purdie CA, Lane DP and Thompson AM: MDM2 SNP309 is associated with high grade node positive breast tumours and is in linkage disequilibrium with a novel MDM2 intron 1 polymorphism. BMC Cancer 8: 281, 2008. PMID: 18828900. DOI: 10.1186/1471-2407-8-281

21 Alhopuro P, Ylisaukko-Oja SK, Koskinen WJ, Bono P, Arola J, Jarvinen HJ, Mecklin JP, Atula T, Kontio R, Makitie AA, Suominen S, Leivo I, Vahteristo P, Aaltonen LM and Aaltonen LA: The MDM2 promoter polymorphism SNP309T-->G and the risk of uterine leiomyosarcoma, colorectal cancer, and squamous cell carcinoma of the head and neck. J Med Genet 42: 694-698, 2005. PMID: 16141004. DOI: $10.1136 /$ jmg.2005.031260 
22 Talseth BA, Meldrum C, Suchy J, Kurzawski G, Lubinski J and Scott RJ: MDM2 SNP309 T>G alone or in combination with the TP53 R72P polymorphism does not appear to influence disease expression and age of diagnosis of colorectal cancer in HNPCC patients. Int J Cancer 120: 563-565, 2007. PMID: 17096342. DOI: $10.1002 / \mathrm{ijc} .22339$

23 Wilkening S, Bermejo JL and Hemminki K: MDM2 SNP309 and cancer risk: a combined analysis. Carcinogenesis 28: 22622267, 2007. PMID: 17827408. DOI: 10.1093/carcin/bgm191

24 Nan H, Qureshi AA, Hunter DJ and Han J: A functional SNP in the MDM2 promoter, pigmentary phenotypes, and risk of skin cancer. Cancer Causes Control 20: 171-179, 2009. PMID: 18814047. DOI: $10.1007 / \mathrm{s} 10552-008-9231-9$

25 Liu G, Wheatley-Price P, Zhou W, Park S, Heist RS, Asomaning K, Wain JC, Lynch TJ, Su L and Christiani DC: Genetic polymorphisms of MDM2, cumulative cigarette smoking and nonsmall cell lung cancer risk. Int J Cancer 122: 915-918, 2008. PMID: 17957785. DOI: $10.1002 / \mathrm{ijc} .23178$

26 Hancox RJ, Poulton R, Welch D, Olova N, McLachlan CR, Greene JM, Sears MR, Caspi A, Moffitt TE, Robertson SP and Braithwaite AW: Accelerated decline in lung function in cigarette smokers is associated with TP53/MDM2 polymorphisms. Hum Genet 126: 559-565, 2009. PMID: 19521721. DOI: 10.1007/s00439-009-0704-Z

27 Hsu SW, Gong CL, Hsu HM, Chao CC, Wang YC, Chang WS, Tsai YT, Shih LC, Tsai CW and Bau DT: Contribution of matrix metalloproteinase-2 promoter genotypes to nasopharyngeal cancer susceptibility and metastasis in Taiwan. Cancer Genomics Proteomics 16: 287-292, 2019. PMID: 31243109. DOI: $10.21873 / \mathrm{cgp} .20133$

28 Yueh TC, Wu CN, Hung YW, Chang WS, Fu CK, Pei JS, Wu MH, Lai YL, Lee YM, Yen ST, Li HT, Tsai CW and Bau DT: The contribution of MMP-7 genotypes to colorectal cancer susceptibility in Taiwan. Cancer Genomics Proteomics 15: 207212, 2018. PMID: 29695403. DOI: $10.21873 /$ cgp.20079

29 Hsu NY, Wang HC, Wang CH, Chiu CF, Tseng HC, Liang SY, Tsai CW, Lin CC and Bau DT: Lung cancer susceptibility and genetic polymorphisms of Exo1 gene in Taiwan. Anticancer Res 29: 725-730, 2009. PMID: 19331228.

30 Liu CJ, Hsia TC, Tsai RY, Sun SS, Wang CH, Lin CC, Tsai CW, Huang CY, Hsu CM and Bau DT: The joint effect of hOGG1 single nucleotide polymorphism and smoking habit on lung cancer in Taiwan. Anticancer Res 30: 4141-4145, 2010. PMID: 21036733

31 Yueh TC, Hung YW, Shih TC, Wu CN, Wang SC, Lai YL, Hsu SW, Wu MH, Fu CK, Wang YC, Ke TW, Chang WS, Tsai CW and Bau DT: Contribution of murine double minute 2 genotypes to colorectal cancer risk in Taiwan. Cancer Genomics Proteomics 15: 405-411, 2018. PMID: 30194081. DOI: $10.21873 / \mathrm{cgp} .20099$

32 Hao XP, Gunther T, Roessner A, Price AB and Talbot IC: Expression of $\mathrm{mdm} 2$ and $\mathrm{p} 53$ in epithelial neoplasms of the colorectum. Mol Pathol 51: 26-29, 1998. PMID: 9624416. DOI: $10.1136 / \mathrm{mp} .51 .1 .26$

33 Momand J, Jung D, Wilczynski S and Niland J: The MDM2 gene amplification database. Nucleic Acids Res 26: 3453-3459, 1998. PMID: 9671804 . DOI: $10.1093 / \mathrm{nar} / 26.15 .3453$
34 Martin K, Trouche D, Hagemeier C, Sorensen TS, La Thangue NB and Kouzarides T: Stimulation of E2F1/DP1 transcriptional activity by MDM2 oncoprotein. Nature 375: 691-694, 1995. PMID: 7791903. DOI: 10.1038/375691a0

35 Xiao ZX, Chen J, Levine AJ, Modjtahedi N, Xing J, Sellers WR and Livingston DM: Interaction between the retinoblastoma protein and the oncoprotein MDM2. Nature 375: 694-698, 1995. PMID: 7791904. DOI: 10.1038/375694a0

36 Ries S, Biederer C, Woods D, Shifman O, Shirasawa S, Sasazuki T, McMahon M, Oren M and McCormick F: Opposing effects of Ras on p53: transcriptional activation of $\mathrm{mdm} 2$ and induction of p19ARF. Cell 103: 321-330, 2000. PMID: 11057904. DOI: 10.1016/s0092-8674(00)00123-9

37 Gudas JM, Nguyen H, Klein RC, Katayose D, Seth P and Cowan $\mathrm{KH}$ : Differential expression of multiple MDM2 messenger RNAs and proteins in normal and tumorigenic breast epithelial cells. Clin Cancer Res 1: 71-80, 1995. PMID: 9815889.

38 Maya R, Balass M, Kim ST, Shkedy D, Leal JF, Shifman O, Moas M, Buschmann T, Ronai Z, Shiloh Y, Kastan MB, Katzir $\mathrm{E}$ and Oren M: ATM-dependent phosphorylation of Mdm2 on serine 395: role in p53 activation by DNA damage. Genes Dev 15: 1067-1077, 2001. PMID: 11331603. DOI: 10.1101/gad. 886901

39 Doll R and Hill AB: Smoking and carcinoma of the lung; preliminary report. $\mathrm{Br}$ Med J 2: 739-748, 1950. PMID: 14772469. DOI: $10.1136 / \mathrm{bmj} .2 .4682 .739$

40 Perlow RA and Broyde S: Evading the proofreading machinery of a replicative DNA polymerase: induction of a mutation by an environmental carcinogen. J Mol Biol 309: 519-536, 2001. PMID: 11371169. DOI: 10.1006/jmbi.2001.4674

41 Valavanidis A, Vlachogianni T and Fiotakis K: Tobacco smoke: involvement of reactive oxygen species and stable free radicals in mechanisms of oxidative damage, carcinogenesis and synergistic effects with other respirable particles. Int J Environ Res Public Health 6: 445-462, 2009. PMID: 19440393. DOI: 10.3390/ijerph6020445

42 Schwartz D and Rotter V: p53-Dependent cell cycle control: response to genotoxic stress. Semin Cancer Biol 8: 325-336, 1998. PMID: 10101798. DOI: 10.1006/scbi.1998.0095

43 Okorokov AL: p53 in a crosstalk between DNA repair and cell cycle checkpoints. Cell Cycle 2: 233-235, 2003. PMID: 12734432.

44 Chen J: The cell-cycle arrest and apoptotic functions of p53 in tumor initiation and progression. Cold Spring Harb Perspect Med 6: a026104, 2016. PMID: 26931810. DOI: 10.1101/ cshperspect.a026104

45 Iwakuma T and Lozano G: MDM2, an introduction. Mol Cancer Res 1: 993-1000, 2003. PMID: 14707282.

Received January 13, 2020

Revised January 29, 2020

Accepted February 3, 2020 